\title{
Climate change and freshwater zooplankton: what does it boil down to?
}

\author{
Csaba Vadadi-Fülöp · Csaba Sipkay • \\ Gergely Mészáros • Levente Hufnagel
}

Received: 4 June 2012/ Accepted: 1 October 2012

(C) Springer Science+Business Media Dordrecht 2012

\begin{abstract}
Recently, major advances in the climatezooplankton interface have been made some of which appeared to receive much attention in a broader audience of ecologists as well. In contrast to the marine realm, however, we still lack a more holistic summary of recent knowledge in freshwater. We discuss climate change-related variation in physical and biological attributes of lakes and running waters, high-order ecological functions, and subsequent alteration in zooplankton abundance, phenology, distribution, body size, community structure, life history parameters, and behavior by focusing on community level responses. The adequacy of large-scale climatic indices in ecology has received considerable support
\end{abstract}

Handling Editor: Piet Spaak.

C. Vadadi-Fülöp $(\bowtie)$

Hungarian Scientific Research Fund Office,

Czuczor u. 10, 1093 Budapest, Hungary

e-mail: vadfulcsab@gmail.com

C. Sipkay

Danube Research Institute of the Hungarian Academy

of Sciences, Jávorka Sándor u. 14, 2131 Göd, Hungary

G. Mészáros

Szent István University, Páter Károly u. 1, 2100 Gödöllő,

Hungary

L. Hufnagel

Department of Mathematics and Informatics,

Corvinus University of Budapest, Villányi út 29-43,

1118 Budapest, Hungary and provided a framework for the interpretation of community and species level responses in freshwater zooplankton. Modeling perspectives deserve particular consideration, since this promising stream of ecology is of particular applicability in climate change research owing to the inherently predictive nature of this field. In the future, ecologists should expand their research on species beyond daphnids, should address questions as to how different intrinsic and extrinsic drivers interact, should move beyond correlative approaches toward more mechanistic explanations, and last but not least, should facilitate transfer of biological data both across space and time.

Keywords Global warming - Daphnia Phenology · Community dynamics $\cdot$ Ecological models

\section{Introduction}

Evidence accumulated over recent decades provided insights as to how climate change, as a significant part of global change, has already altered and is projected to further alter phenology, distribution, abundance, and invasion potential of species as well as biodiversity at a global or nearly global scale (Dukes and Mooney 1999; Sala et al. 2000; Walther et al. 2002; Parmesan and Yohe 2003; Root et al. 2003; Thomas et al. 2004). Lakes and rivers (Williamson et al. 2008; Adrian et al. 2009; Schindler 2009) as well as ongoing plankton monitoring programmes (Hays et al. 2005) 
have been recognized as sentinels of global change. Why plankton are particularly good indicators of climate change is discussed in Hays et al. (2005) and Richardson (2008) in exhaustive details. Cladoceran and ostracod remains preserved in the sediment record also have been used to reconstruct past climatic changes in lakes (Chivas et al. 1985; Lotter et al. 1997; Battarbee 2000). Zooplankton are key components of aquatic food webs. Analogous with Drosophila in genetics, Daphnia is known as a model organism in aquatic ecology (Lampert 2006, 2011). Therefore, a better understanding of the role of climate change in altering zooplankton dynamics, structure, and function is of high scientific and economic value. However, we still lack a more holistic summary of recent knowledge of climate change from a freshwater zooplankter perspective.

Temperature is one of the most important factors accounting for variation in nearly all biological rates and times, including metabolic rate (Gillooly et al. 2001), population growth (Savage et al. 2004), life span (Gillooly et al. 2001), and developmental time (Gillooly et al. 2002). Metabolic theory (Brown et al. 2004) suggests that metabolic rate, as a function of body size and temperature, controls ecological processes at all levels of organization from life history characteristics to species interactions and ecosystem processes. Also, virulence varies with temperatures altering the outcome of host-parasite interactions (Mitchell et al. 2005). Temperature rise, however, is not the only phenomenon accompanying climate change, variation in precipitation, wind and subsequent floods, droughts, altered mixing regimes all represent major forcing on the abiotic and biotic template.

This paper aimed at summarizing the observed and projected future effects of climate change on freshwater zooplankton from the ecologist's perspective. Thus, we focus on the community level responses, and physiological attributes are discussed in more limited details. We dedicated an extra section for modeling studies, as this promising stream of ecology is of particular applicability in climate change research owing to the inherently predictive nature of this field. Not surprisingly, the literature is skewed toward lake plankton, but wherever possible, we draw on examples from running waters as well.

Figure 1 summarizes the documented and projected direct and indirect effects of climate change on freshwater zooplankton within an environmental and trophic framework. First, we have a look at the possible effects of large-scale climatic fluctuations on zooplankton community dynamics. Then, we turn to the trophic level responses and begin to consider variation in community attributes one after the other. We devote an extra section to ultraviolet radiation (UVR) and subsequent variation in zooplankton physiology and community dynamics and demonstrate why and how this has been linked to climate change. We close with a brief review of some sophisticated modeling approaches favored by ecologists in order to gain more information than empirical and experimental studies can provide.

\section{Large-scale climatic fluctuations}

Here, we briefly discuss some well-known large-scale climate patterns focusing on the North Atlantic Oscillation (NAO) and then begin to consider the effects of those on freshwater zooplankton communities.

The NAO is a large-scale climatic oscillation of atmospheric mass between the subtropical Azores high and the subpolar Iceland low, ranging from central North America to Europe and much into Northern Asia. In a large part of the northern hemisphere, climate variability is assumed to be influenced by the NAO, particularly in the winter term (Hurrell 1995). The measure of this oscillation, the winter NAO index, is the difference of normalized sea level pressures between Lisbon, Portugal, and Iceland, Stykkisholmur (Hurrell 1995). The NAO index exhibited a positive trend toward larger values, that is, a positive phase over the 70s, 80s, and 90 s (Fig. 2), bringing to milder and wetter winters to western and northern Europe, whereas colder and drier conditions to the Mediterranean region, northern Canada, and Greenland (Hurrell 1995). A similar phenomenon is the El Nino-Southern Oscillation (ENSO) affecting climate variability worldwide, but particularly in the tropical Pacific (Allan et al. 1996) and the Pacific Decadal Oscillation (PDO) accounting for major variation in the North Pacific climate (Mantua et al. 1997).

North Atlantic Oscillation has been recognized as a driving force behind variation in phenology, abundance, distribution, and interspecific relationships acting through direct, indirect, and integrated effects in variable groups and environments (Ottersen et al. 2001; Stenseth et al. 2002). Although the NAO 
Fig. 1 Conceptual model of the possible direct and indirect effects of climate change on freshwater zooplankton. Solid arrows indicate linkage between components while dashed arrows indicate feedbacks. Dotted lines indicate synchronizing effects of NAO, ENSO, and PDO (for more details, see the text). Plus and minus signs indicate potential positive and negative effects on zooplankton. Note, that this model does not represent the food web and the environment in detail, rather sketches relevant tracks of climate change-related impacts from a zooplankter perspective

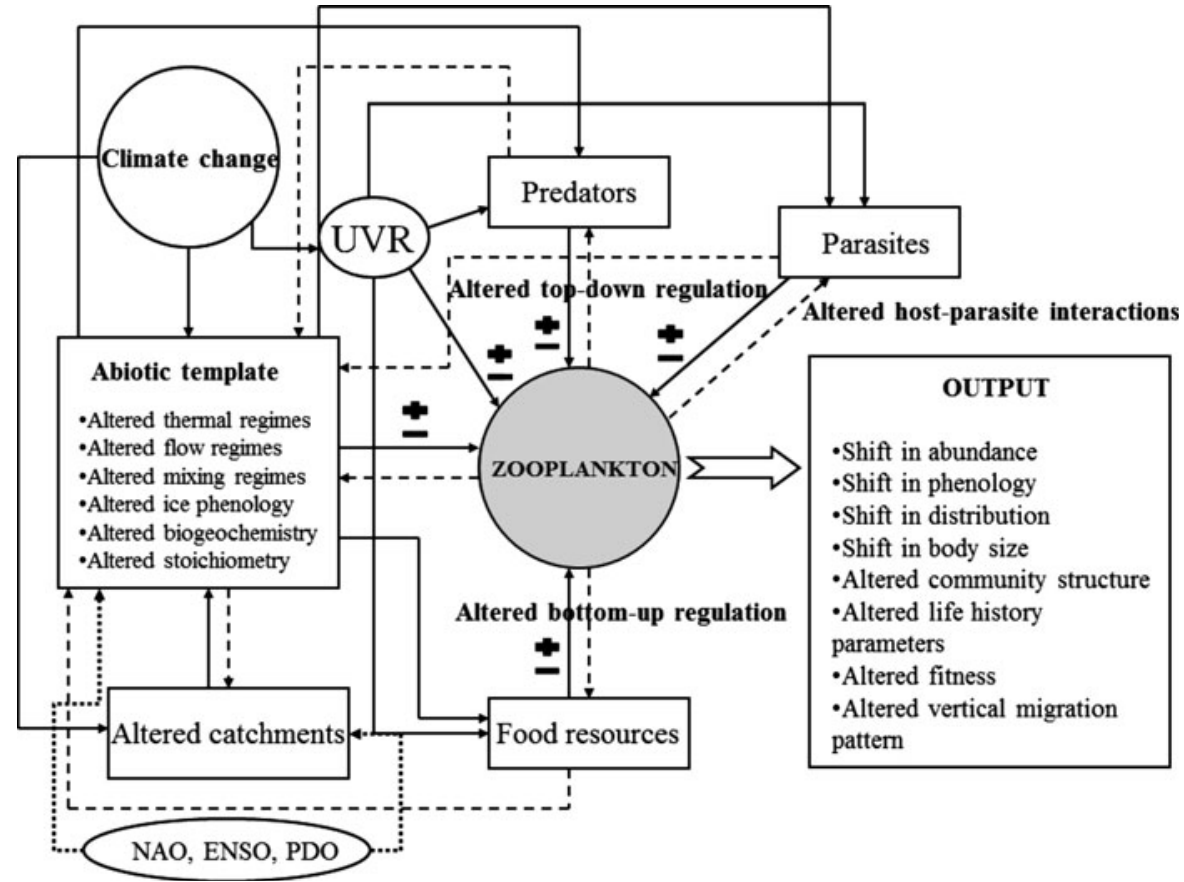

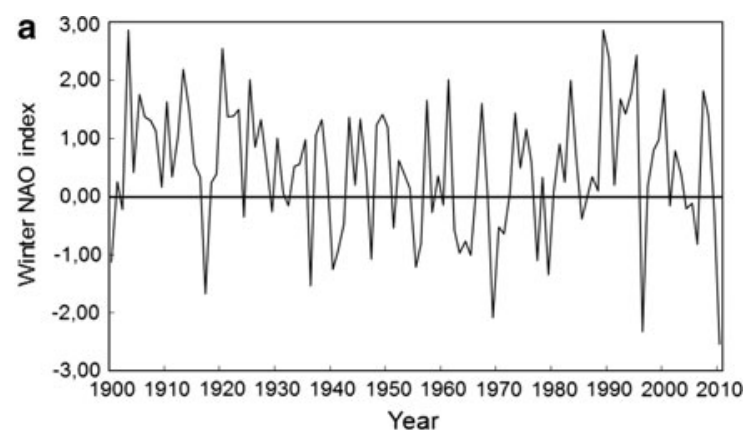

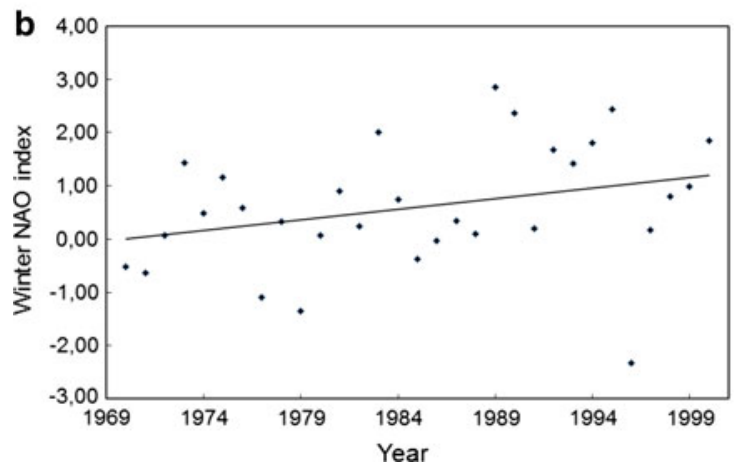

Fig. 2 a The winter (December-March) NAO index throughout the twentieth century and beyond. Data were obtained from the Climatic Research Unit, University of East Anglia (source http://www.cru.uea.ac.uk/cru/data/nao/). b The positive phase of the NAO with the trendline accounts for a major variation of winter climate, it has a memory effect in the community, lasting to almost half a year (Straile 2000; Gerten and Adrian 2000; Blenckner et al. 2007). Large-scale climate indices can have even higher explanatory power than local weather variables (Hallett et al. 2004), because they integrate several weather components both in space and time and thus can be considered as appropriate "weather packages" (Stenseth and Mysterud 2005). Contrasting results obtained from local weather variables and large-scale climate indices may improve our understanding of what features of weather may account for the pattern observed.

The NAO has been linked to zooplankton successional events (earlier CWP: clear-water phase in high NAO years) (Straile 2000; Gerten and Adrian 2000; Wagner and Benndorf 2007) and abundances (Straile and Geller 1998; George 2000; Blenckner et al. 2007; Straile and Müller 2010).

There is now ample evidence of large-scale coherent response of zooplankton to NAO (Straile 2002; Blenckner et al. 2007). ENSO also has been found to synchronize the dynamics of several zooplankton taxa in north-temperate lakes (Rusak et al. 2008). PDO and ENSO have been linked to Daphnia abundance increase in Castle Lake (Park et al. 2004). In response to the positive phase of the PDO, spring breakup dates 
have shifted earlier in Lake Aleknagik over recent decades and, as a result, daphnids increased in abundance in summer (Schindler et al. 2005). By extending the duration of the stratification period, ENSO and PDO influenced phytoplankton and zooplankton phenologies in Lake Washington (Winder and Schindler 2004a).

The observed behavior of the NAO index, that is, a trend toward a more positive phase, has resulted in a weakening winter stress allowing earlier population growth, reduced mortality (Straile and Stenseth 2007), and overwintering populations (Adrian and Deneke 1996). However, fall warming can have severe consequences for zooplankton overwintering success through early emergence of resting stages, the result of which can be the loss of the cohort, and through switching from sexual to asexual reproduction resulting in delayed production and reduced number of ephippial resting eggs, respectively (Chen and Folt 1996).

Climate variability, such as El Nino-related droughts, may alter zooplankton population dynamics by triggering the emergence of resting stages residing in lake sediments (Arnott and Yan 2002). This may be of significant risk by depleting the egg bank and thus reducing the number of potential colonists when environmental conditions improve (Arnott and Yan 2002). On the other hand, diapausing strategies can help certain species to withstand unfavorable conditions under future environmental change (Hairston 1996).

\section{Food web-related effects: a zooplankter perspective}

\section{Bottom-up effects}

There is now convincing empirical evidence for increasing dominance of cyanobacteria in response to climate change (Robarts and Zohary 1987; Adrian and Deneke 1996; Mooij et al. 2005; Shatwell et al. 2008; Paul 2008; Paerl and Huisman 2009; Wagner and Adrian 2009). It has received strong experimental (De Senerpont Domis et al. 2007a; Jöhnk et al. 2008) and theoretical (Elliott et al. 2005; Elliott 2010) supports as well; however, some studies have not found better performance of cyanobacteria under rising temperatures (e.g., Moss et al. 2003). Cyanobacteria in general have an arsenal of properties which enable these algae to thrive under climate change and outcompete other phytoplankton including (1) buoyancy regulation, (2) $\mathrm{N}$-fixing abilities, (3) UVR tolerance, and (4) better performance under elevated temperatures (Spencer and King 1987; Robarts and Zohary 1987; Paul 2008). Increased cyanobacteria dominance does not favor herbivorous zooplankton for some reasons: (1) cyanobacteria are poor-quality food for zooplankton (Haney 1987; Brett and Müller-Navarra 1997; Wilson et al. 2006), (2) their filaments cause mechanical interference with the feeding apparatus of filter feeders ("clogging") (Webster and Peters 1978; Porter and McDonough 1984), (3) they can be toxic for consumers (Hietala et al. 1997; Hansson et al. 2007a), but the direct harmful effects of cyanobacterial toxins to zooplankton have recently been questioned (Wilson et al. 2006). It has been shown that the mechanical interference of filaments with the filtering combs of daphnids decreases with increasing viscosity and declining temperature (Abrusán 2004). Note, however, that small zooplankters (cyclopoid copepods, small-bodied cladocerans, and rotifers) can escape from competition with large-bodied herbivores, for example, Daphnia, and can even benefit from cyanobacteria dominance (Fulton and Paerl 1988; Hansson et al. 2007a; Dupuis and Hann 2009a). Also, calanoid copepods have found to be better suited to cyanobacterial blooms than do cladocerans (Haney 1987).

Thermal stratification and related vertical mixing strongly determine nutrient and light availability for phytoplankton (Diehl et al. 2002). In deep lakes, algal growth in spring is initiated by the stratification of the water column allowing algal cells to be exposed to higher light levels (Reynolds 1984; Gaedke et al. 1998). Many freshwater systems have experienced increased stratification (reduced mixing) and a longer duration of stratification period (King et al. 1997; Gaedke et al. 1998; Livingstone 2003; Winder and Schindler 2004a; Coats et al. 2006; Peeters et al. 2007a). As sinking velocities are a function of cell size, reduced vertical mixing favors small-sized species, species with buoyancy regulation (e.g., cyanobacteria) and motile flagellates over diatoms and green algae with higher sinking velocities (Strecker et al. 2004; Huisman et al. 2004; Winder and Hunter 2008) and thus may alter community structure of phytoplankton. All those are of crucial importance for consumers, as diatoms are known as high-quality food 
for zooplankton because of their high content of HUFA (highly unsaturated fatty acids) (Brett and Müller-Navarra 1997), whereas cyanobacteria may have several negative effects on grazers as discussed earlier in this section. Increased stratification and reduced mixing also can cut nutrient flux from deeper layers. As a consequence, nutrient conditions in the epilimnion can be limiting for algae (George et al. 1990) and decreased phytoplankton production can lead to the starvation of zooplankton; for instance, in Esthwaite Water, strongly reduced Daphnia abundance in "calm years" was assumed to be the result of food limitation because shallow mixing hampered algal growth through nutrient depletion (George 2000). Daphnids, however, may benefit directly from stratification through a positive response to increased water temperatures and/or indirectly via increased phytoplankton productivity (Straile and Geller 1998).

River flows are projected to decrease or increase worldwide depending on the climate of the catchments (Arora and Boer 2001; Kundzewicz et al. 2007; Johnson et al. 2009) and thus may shape bottom-up effects on zooplankton. Depending on the future flow regime, phytoplankton abundance may considerably increase or decrease in running waters (Phlips et al. 2007), often with an increasing contribution of cyanobacteria under low-flow conditions (Jones et al. 2011).

\section{Top-down effects}

Climate warming-related change in habitat structure can induce strong cascading effects in pelagic food webs. A recent example of how this works comes from the study of Manca and DeMott (2009). Climate warming linked change in thermal refuge from fish predators allowed the predatory cladoceran Bythotrephes longimanus (Leydig 1860) to strongly increase in abundance and suppress the population of Daphnia hyalina galeata. Warming can increase the risk of predation by prolonging the period of predators spending in the open water. For example, Leptodora kindtii (Focke, 1844) predation on Daphnia galeata (Sars, 1864) advanced by 13 days per degree warming in Bautzen reservoir, Germany (Wagner and Benndorf 2007).

Climate warming may allow increased predation pressure on zooplankton due to improving growing conditions and decreasing winter mortality of fish (Moore et al. 1996; Mehner 2000; Benndorf et al.
2001; Gyllström et al. 2005; Schindler et al. 2005; Jeppesen et al. 2009, 2010). Furthermore, fish may become smaller and more omnivorous with increasing temperatures implying higher predation on zooplankton (Jeppesen et al. 2010). An important consideration here is that high densities of planktivorous fish and related strong predation pressure, as indirect effects, have the potential to mask the effect of climate change on zooplankton (Schindler et al. 2005). As a result of climate change and resulted changes in lake physical properties, an increase in thermal habitat for cold-, cool-, and warm-water fish was recognized for large lakes and partly for small lakes as well (De Stasio et al. 1996; Fang et al. 1999). Global warming may change the habitat overlap between planktivorous fish and their prey both spatially and temporally, but the outcome of this predator-prey interaction may vary with species and localities (De Stasio et al. 1996; Helland et al. 2007). High predation pressure by fish may constrain zooplankton vertical migration under climate warming (De Stasio et al. 1996). In shallow lakes, fish kills are expected to increase due to decreasing water levels (McGowan et al. 2005) and shortening of the ice cover period will, in turn, favor fish (Fang et al. 1999; Jackson et al. 2007).

\section{Shift in phenology}

Phenology is the study of seasonally recurring events in nature and it has been widely used as indicator of climate change (Walther et al. 2002; Root et al. 2003; Visser and Both 2005). Phenological response to global warming is now fairly acknowledged and documented in a variety of plant and animal species worldwide (see Parmesan and Yohe 2003; Root et al. 2003; Parmesan 2007; Thackeray et al. 2010). When the time lag between population peaks of prey and predator increases, a mismatch between food availability and food requirement may arise (Cushing 1969). Climate change is increasingly recognized as the driver of such mismatches between predator and prey by triggering phenological events in an asynchronous way (Durant et al. 2007).

This decoupling is a result of different phenological responses of interacting species. Such decoupling was reported from Lake Windermere (George and Harris 1985) and Lake Washington (Winder and Schindler 2004b). In the latter case, an advancement in the onset 
of thermal stratification in spring resulted in a forward shift of the phytoplankton bloom. While the rotifer Keratella cochlearis (Gosse, 1851) appeared to adapt its phenology, Daphnia pulicaria (Forbes, 1893) was not able to do so and declined in abundance. The authors proposed that the different life history strategy and thus the different hatching cues used by the cladoceran may explain the mismatch. For the marine alternatives, see Edwards and Richardson (2004) and Richardson (2008). In order to interpret these shifts in phenology, Visser and Both (2005) called for a yardstick, a measure that will reflect a species success or failure to match its environment under climate change. Such a yardstick can be the shift in phenology of food abundance. Decoupling of the trophic relationship between the keystone herbivore Daphnia and its algal prey can result in the absence of the spring clear-water phase as shown by De Senerpont Domis et al. (2007b) with a seasonally forced predator-prey model.

Climate change-related change in lake physical properties and subsequent change in algal numbers and community structure might explain much of the variation in phenology. There is growing evidence for an advancement of phenological events in zooplankton (Table 1). Observed shifts in phenology ranged from 1 week in Bosmina sp. and Keratella sp. (Gerten and Adrian 2000) to 3 months in Bythotrephes longimanus (Manca et al. 2007). Theoretical studies also suggest that phenological events in freshwater zooplankters will advance considerably (Schalau et al. 2008; Sipkay et al. 2008; Vadadi-Fülöp et al. 2009). An important consideration here is the advancement in the timing of the CWP (e.g., Gerten and Adrian 2000; Straile 2002; Wagner and Benndorf 2007).

Zooplankton phenology is a result of selective forces in the benthic and the pelagic, thus hatching from dormant stages may affect zooplankton population dynamics and seasonal succession (Gyllström and Hansson 2004). Spring warming is likely to induce earlier emergence from resting stages (Chen and Folt 2002). Temperature and photoperiod are the major factors affecting emergence in zooplankton (Gyllström and Hansson 2004; Gilbert and Schröder 2004). Increased temperatures and shorter photoperiod have found to decrease Daphnia emergence from resting eggs while rotifers were less affected (Dupuis and Hann 2009b). Dupuis and Hann (2009b) argued that lakes with strong dependence on the egg bank, that is, low portion of overwintering individuals, are likely to fail to control algal growth because Daphnia hatching success decreases with climate change. Different zooplankton species use different temperature-photoperiod cues; therefore, the outcome will vary with environmental forcing (Dupuis and Hann 2009b). Earlier ice-out was associated with increased hatchling abundance of Daphnia pulicaria in both the laboratory and in Oneida Lake (Cáceres and Schwalbach 2001), suggesting a possibility to advance phenological events in this species. Sediment resuspension and sediment mixing are likely to facilitate hatching (Hairston and Kearns 2002; Gilbert and Schröder 2004), both of which are more likely to occur in shallow lakes (Gilbert and Schröder 2004). Hatching often occurs over a short period, particularly in early spring (Cáceres 1998; Gilbert and Schröder 2004); thus, climate warming-related change in temperature and photoperiod cues of dormant stages are very likely to affect emergence and zooplankton dynamics.

\section{Shift in body size}

It has long been acknowledged that predation and filamentous algae can constrain zooplankton size structure (Brooks and Dodson 1965; Webster and Peters 1978; Porter and McDonough 1984). Furthermore, Hansson et al. (2007a) suggest that even cyanobacterial toxins can cause a reduction in adult size of Daphnia. Climate warming may have both direct and indirect effects on body size. It has been shown that increasing temperatures shifted the zooplankton assemblage toward smaller forms (Moore and Folt 1993; Strecker et al. 2004; Molinero et al. 2006; Dupuis and Hann 2009a); however, some studies have not supported these findings (McKee et al. 2002; Gyllström et al. 2005). As size structure of zooplankton has high-order ecological functions of which energy flow and food web interactions are readily relevant to this topic (see Alvarez-Cobelas and Rojo 2000), its reduction is likely to alter water clarity, nutrient regeneration, and fish abundances (Moore et al. 1996).

Body size in copepods (Gophen 1976a), cladocerans (McKee and Ebert 1996; Giebelhausen and Lampert 2001; Chen and Folt 2002; McKee et al. 2002), rotifers (Stelzer 2002), and protists (Atkinson 
Table 1 Documented and simulated phenological changes in freshwater zooplankton in response to climate change

\begin{tabular}{|c|c|c|c|c|c|c|}
\hline Site & $\begin{array}{l}\text { Type of } \\
\text { water }\end{array}$ & References & $\begin{array}{l}\text { Zooplankton } \\
\text { maximum }\end{array}$ & Species & $\begin{array}{l}\text { Functional } \\
\text { group }\end{array}$ & Sampling period \\
\hline $\begin{array}{l}\text { Lake Maggiore } \\
\text { (Italy) }\end{array}$ & Deep & $\begin{array}{l}\text { Manca } \\
\text { et al. } \\
(2007)\end{array}$ & $\begin{array}{l}\text { Forward shift } \\
\text { by } 3 \text { months }\end{array}$ & $\begin{array}{r}\text { Bythotrephes } \\
\text { longimanus }\end{array}$ & Predator & 1981-2003 \\
\hline $\begin{array}{l}\text { Lake Maggiore } \\
\text { (Italy) }\end{array}$ & Deep & $\begin{array}{l}\text { Visconti } \\
\text { et al. } \\
(2008)\end{array}$ & $\begin{array}{l}\text { Forward shift } \\
\text { by } 2 \text { months }\end{array}$ & Daphnia sp. & Filter feeder & 1999-2003 \\
\hline $\begin{array}{l}\text { Lake Constance } \\
\text { (Germany, } \\
\text { Switzerland, } \\
\text { Austria) }\end{array}$ & Deep & $\begin{array}{l}\text { Straile and } \\
\text { Geller } \\
(1998)\end{array}$ & $\begin{array}{l}\text { Forward shift } \\
\text { by } 2 \text { months }\end{array}$ & Daphnia sp. & Filter feeder & 1979-1995 \\
\hline $\begin{array}{l}\text { Lake } \\
\text { Washington } \\
\text { (US) }\end{array}$ & Deep & $\begin{array}{l}\text { Winder and } \\
\text { Schindler } \\
(2004 b)\end{array}$ & $\begin{array}{l}\text { Forward shift } \\
\text { by } 3 \text { weeks }\end{array}$ & Keratella cochlearis & Filter feeder & 1962-1995 \\
\hline $\begin{array}{l}\text { Lake } \\
\text { Washington } \\
\text { (US) }\end{array}$ & Deep & $\begin{array}{l}\text { Winder } \\
\text { et al. } \\
(2009)\end{array}$ & $\begin{array}{l}\text { Forward shift } \\
\text { by } \\
2-4 \text { weeks }\end{array}$ & $\begin{array}{l}\text { Leptodiaptomus } \\
\text { ashlandi }\end{array}$ & Filter feeder & $1962-2005$ \\
\hline $\begin{array}{l}\text { Müggelsee } \\
\text { (Germany) }\end{array}$ & Shallow & $\begin{array}{l}\text { Gerten and } \\
\text { Adrian } \\
(2000)\end{array}$ & $\begin{array}{l}\text { Forward shift } \\
\text { by } \\
1-2 \text { weeks }\end{array}$ & $\begin{array}{l}\text { Bosmina } \text { sp. (1 week), } \\
\text { Keratella sp. } \\
\text { (1 week), Daphnia } \\
\text { sp. }(2 \text { weeks) }\end{array}$ & Filter feeder & 1988-1998 \\
\hline $\begin{array}{l}\text { Müggelsee } \\
\text { (Germany) }\end{array}$ & Shallow & $\begin{array}{l}\text { Adrian } \\
\text { et al. } \\
(2006)\end{array}$ & $\begin{array}{c}\text { Forward shift } \\
\text { by } 1 \text { month }\end{array}$ & Daphnia sp. & Filter feeder & 1979-2003 \\
\hline $\begin{array}{l}\text { Temperate } \\
\text { lakes }\end{array}$ & (Model) & $\begin{array}{l}\text { Schalau } \\
\text { et al. } \\
(2008)\end{array}$ & $\begin{array}{c}\text { Forward shift } \\
\text { by } 54 \text { days }\end{array}$ & Daphnia galeata & Filter feeder & $\begin{array}{l}\text { In case of a forward shift of } \\
\text { the vernal temperature } \\
\text { increase by } 60 \text { days (period } \\
\text { not defined) }\end{array}$ \\
\hline $\begin{array}{l}\text { Danube river } \\
\text { (Hungary) }\end{array}$ & (Model) & $\begin{array}{l}\text { Sipkay } \\
\text { et al. } \\
\text { (2008) }\end{array}$ & $\begin{array}{l}\text { Forward shift } \\
\text { by } \\
1-1.5 \text { months }\end{array}$ & Cyclops vicinus & $\begin{array}{l}\text { Predator } \\
\text { (facultative } \\
\text { herbivore) }\end{array}$ & $2070-2100$ \\
\hline $\begin{array}{l}\text { Outdoor } \\
\text { mesocosm } \\
\text { (Hungary) }\end{array}$ & (Model) & $\begin{array}{l}\text { Vadadi- } \\
\text { Fülöp } \\
\text { et al. } \\
\text { (2009) }\end{array}$ & $\begin{array}{l}\text { Forward shift } \\
\text { by } \\
1-2 \text { months }\end{array}$ & $\begin{array}{l}\text { Eudiaptomus } \\
\text { zachariasi }\end{array}$ & Filter feeder & 2050 and $2070-2100$ \\
\hline
\end{tabular}

The term "Type of water" refers to the type of water body whether it is a deep or a shallow lake. Some modeling studies are also discussed here indicated in parentheses. The term "Sampling period" refers to the period data were collected and the period simulations covered, respectively

et al. 2003) was smaller when reared under higher temperatures; however, some studies seem to contradict those findings (Atkinson 1995; Weetman and Atkinson 2004). Increasing temperatures have been coupled with decreasing body size in over $80 \%$ of aquatic and terrestrial ectotherms studied (Atkinson 1994). Several explanations have been proposed to elucidate those findings (see Atkinson 1994; Atkinson and Sibly 1997; Weetman and Atkinson 2004). Perhaps, the most important view is that higher temperatures are coupled with increasing metabolic costs (e.g., Gophen 1976b). In a very recent meta- analysis on ectotherm aquatic organisms including also zooplankton, there was evidence of decreasing body size both at the community and individual levels in response to climate change (Daufresne et al. 2009).

\section{Shift in abundance}

Analysis of long-term zooplankton time series suggests that increased climate variability may increase the frequency of extreme demographic events either increasing or decreasing long-run population growth 
rates (Drake 2005). Simulations highly support this view, by showing that the amplitude of fluctuations of the herbivorous zooplankton stock increases with temperature while the mean biomass and minimum values decrease in comparison with steady state predictions (Norberg and DeAngelis 1997). When subject to environmental stress, the mean densities of all interacting species in a community will shift in a complex pattern determined by the sensitivity of all species to the environmental stressor and the indirect effects of species interactions (Ives 1995). To disentangle the direct effects of increased water temperature from the indirect effects of species interactions on the abundance of zooplankton remains to be a key question. Some studies have shown that zooplankton abundance benefited from increased water temperatures indirectly through increased food resources (Molinero et al. 2006; Visconti et al. 2008) or increased spatio-temporal refuge from predators (Manca et al. 2007). In contrast, the response of Daphnia to increased water temperatures was merely a direct effect and was not mediated by change in algal numbers or mixing depth in deep Lake Constance (Gaedke et al. 1998; Straile 2000) and Lake Baikal (Hampton et al. 2008). Recent evidence suggests that the response of zooplankton to warming is strongly dependent on the temporal pattern of elevated water temperatures rather than on a warming at a fixed time (Huber et al. 2010). Warmer water temperatures, however, do not warrant change in zooplankton biomass either directly or indirectly (McKee et al. 2002; Arnott et al. 2003).

Shallow lakes do not stratify and thus primary production does not depend on the onset of stratification in spring, but rising temperatures can fuel algal blooms often associated with high cyanobacteria biomass (Mooij et al. 2007; Dupuis and Hann 2009a). As a consequence, daphnids decrease in abundance while small forms (bosminids, rotifers) often increase their numbers (Dupuis and Hann 2009a). Shallow lakes can abruptly shift from a macrophyte-dominated clearwater state to a more turbid state where phytoplankton prevail and vice versa (Scheffer et al. 1993). The turbid state does not favor zooplankters due to harmful algal blooms, lack of refugium (due to the absence of macrophytes), and increased predation pressure (Scheffer et al. 2001; Mooij et al. 2007; Scheffer and Van Nes 2007). There is emerging evidence that climate warming can lead to such abrupt shifts between alternative stable states (Scheffer et al. 2001; Folke et al. 2004; Scheffer and Van Nes 2007). The role of zooplankton grazing in stabilizing the macrophyte-dominated clear-water state of lakes has long been acknowledged (Lampert et al. 1986).

Duration of ice cover and spring breakup dates has been linked to large-scale atmospheric forcing both in deep (Schindler et al. 2005) and shallow (Dokulil and Herzig 2009) lakes. Ice conditions also act upon phytoplankton and zooplankton dynamics severely (Dokulil and Herzig 2009). In a shallow polymictic lake, ice duration affected the timing and magnitude of the spring abundance of rotifers and daphnids but not of bosminids and cyclopid copepods (Adrian et al. 1999). In deep Lake Aleknagik, earlier breakup dates were associated with increased Daphnia densities, but they had a weak effect on other crustaceans (Schindler et al. 2005). Preston and Rusak (2010) found a negative relationship between ice-off date and annual zooplankton density in Northern Wisconsin lakes. Similarly to lakes, rivers have experienced a decline in ice cover duration over recent decades (Magnuson et al. 2000) and ice cover variability has been linked to atmospheric forcing (Yoo and D’Odorico 2002).

\section{Shift in diversity}

Climate change has been shown and projected to affect freshwater biodiversity through altering species extinction rates, causing range shift in species distribution, altering invasion success of non-native species and fuelling regime shifts (Sala et al. 2000; Mooij et al. 2005; Wrona et al. 2006; Heino et al. 2009). The linkage between diversity and ecosystem stability has long been puzzled ecologists giving rise to one of the most illustrious debates in ecology. A large body of evidence suggests that diversity contributes to ecosystem stability, although not the driver of this relationship (McCann 2000; Loreau et al. 2001). By the reduction in the temporal variation and increasing the temporal mean of productivity, higher species richness warrants ecosystem functioning to be maintained in a fluctuating environment (Insurance Hypothesis, Yachi and Loreau 1999). If diversity continues to decline as has been reported in a global extent (Sala et al. 2000), we expect this will be further exacerbated by some internal mechanisms. Theory suggests that weak interactions in food webs attenuate strong destabilizing consumer- 
resource interactions and thus tend to stabilize communities (McCann et al. 1998). Decreasing biodiversity is likely to increase the overall mean interaction strength between species, and thus increase the probability that ecosystems undergo destabilizing dynamics and collapses (McCann 2000; Perkins et al. 2010).

It has been shown that diversity increases with increasing temperatures and this pattern is fairly predictable from the biochemical kinetics of metabolism (Allen et al. 2002), which may act against diversity loss at some regions. Indeed, it has been suggested that zooplankton diversity may increase in the boreal region as a result of a northward shift of some species (Schindler 1997; Heino et al. 2009). Microcosm experiments on aquatic microbes showed that warming increased extinction risk of top predators and herbivores disproportionately, while it had only a weak effect on producers and bacterivores (Petchey et al. 1999). Zooplankton species richness seems to be sensitive to climate forcing even at a short timescale (Stemberger et al. 1996). In some Northern Wisconsin lakes, Preston and Rusak (2010) did not found significant effect of interannual climate variability (represented as ice cover variability) on zooplankton diversity and density was inversely related to ice-off dates though. In microcosm experiments, warming did not affect cladoceran diversity, instead top-down and bottom-up effects were of crucial importance in regulating it (McKee et al. 2002).

In a very recent meta-analysis incorporating 53 lakes in the temperate zone over North America and Europe, Shurin et al. (2010) suggested that temperature variability in lakes favors zooplankton species richness on interannual and seasonal timescales as well. In rivers, the flow regime is thought to be a major driver of biodiversity and ecosystem integrity (Poff et al. 1997; Poff 2002), the magnitude, duration, and timing of which have undergone remarkable changes over recent times (Kundzewicz et al. 2007), with potential implications for zooplankton diversity. One example comes from the Daugava River (Belarus, Latvia), where a decline in zooplankton diversity has been documented over recent decades (Deksne et al. 2010).

\section{Shift in distribution and invasion}

Under a warming climate, species are expected to shift their distribution toward higher altitudes and latitudes.
There is some evidence to confirm climate changerelated range shifts in freshwater zooplankton (Schindler 1997; Sarma et al. 2005; Heino et al. 2009). In general, there is more evidence for range expansions than range retractions in response to climate change, although it appears to be confounded by interpretation and sampling failures (Thomas et al. 2006). Instead of such shifts in species distribution, the success of invasive or imported species in freshwater systems seems to be a more apparent phenomenon with regard to climate change.

Biological invasions are now acknowledged as a significant component of global environmental change (Vitousek et al. 1997), which, in turn, is likely to exacerbate the competitive and ecosystem-level impacts of invasions (Dukes and Mooney 1999). Altered thermal and stream flow regimes may influence the pool and the establishment of non-native species and alter the impact of those colonists (Rahel and Olden 2008). One of the most striking and well-documented examples of climate change-related invasions in freshwater zooplankton is the invasion success of Daphnia lumholtzi (Sars, 1885) in southern US reservoirs (Havel and Medley 2006). This subtropical Old World cladoceran appears to take advantage of the late summer thermal niche, when water temperatures often exceed $25{ }^{\circ} \mathrm{C}$ and native cladocerans decline in abundance concurrent with low-quality food (Work and Gophen 1999; Lennon et al. 2001). Furthermore, reproductive rates of $D$. lumholtzi have been shown to be comparable with those of other daphnids and at temperatures above $25^{\circ} \mathrm{C}, D$. lumholtzi can outperform some Daphnia spp. (Lennon et al. 2001). Despite its success, $D$. lumholtzi is not expected to have major impact on the native zooplankters, as it occupies only a narrow temporal window during plankton succession (Work and Gophen 1999).

As a result of Bythotrephes longimanus invasion, species richness, abundance, and diversity of native zooplankton, particularly cladocerans, strongly declined in some North American lakes (Yan et al. 2001; Strecker et al. 2006). Studies on European and American populations of $B$. longimanus revealed that abundance and invasion success of Bythotrephes were linked to the duration and thickness of a deep, warmwater refuge from planktivorous fish (Yan et al. 2001; Manca et al. 2007; Manca and DeMott 2009) and thus were associated with climate change-related variation in lake thermal properties at least in Lake Maggiore (Manca et al. 2007; Manca and DeMott 2009). 


\section{Effect of ultraviolet radiation}

Ozone depletion-related increase in solar UVR is now fairly recognized, but recent studies pointed out that global warming can increase ozone depletion by further cooling the stratosphere (Shindell et al. 1998; Hartmann et al. 2000) and thus affecting UV stress in freshwater. The major determinant of UV penetration into the water is DOC (dissolved organic carbon), the concentration of which, in turn, can be regulated by climate variability (Williamson et al. 1996; Cooke et al. 2006). Precipitation increases DOC and thus reduces UV transparency in lakes (Williamson and Rose 2010). Decreasing concentrations of DOC often accompany lake acidification; therefore, zooplankton inhabiting acidified lakes are likely to experience increased UV stress (Schindler et al. 1996; Williamson et al. 1996). In stratified lakes, UVR in the epilimnion can damage zooplankton under oligotrophic, but not under eutrophic conditions (Zagarese et al. 1994; Williamson et al. 1994), whereas shallow waters are subject to increased UV penetration. Grazing may increase UV transparency through decreasing the density and altering the size structure of phytoplankton or decreasing the release of dissolved organic matter (DOM) by phytoplankton; thus, zooplankton can contribute to the development of a UV clear-water phase (Williamson et al. 2007). UVR can also affect survival and fecundity of zooplankton (Leech and Williamson 2000; Grad et al. 2003; Persaud and Williamson 2005), as well as alter abundance of food resources or predators ("solar cascade hypothesis"Williamson 1995; Williamson et al. 1999).

Three major mechanisms help a zooplankter to cope with UV stress, including (1) accumulation of photoprotective compounds, such as carotenoids or mycosporine-like amino acids (MAAs), (2) performing DNA repair mechanisms (e.g., photoenzymatic repair-PER), and (3) avoiding surface waters through undergoing diel vertical migration (DVM) (Leech and Williamson 2000). Recent plankton ecology recognizes UVR as a contributing force behind DVM in low-DOC lakes (Storz and Paul 1998; Alonso et al. 2004; Williamson et al. 2011), predation and other mechanisms are thought to be more often the cause of such behavior in lakes with higher DOC content (Leech et al. 2005).

Ultraviolet radiation tolerance has not been found to be related to zooplankton body size or lake transparency (Leech and Williamson 2000); however, it has been found to vary with age (Leech and Williamson 2000; Grad et al. 2003) and taxon (Cabrera et al. 1997; Leech and Williamson 2000; Häder et al. 2003). Rotifers and copepods appeared to be less sensitive to UVR than cladocerans (Leech and Williamson 2000; Leech et al. 2005), raising the concern of altering ecosystem function (Leech and Williamson 2000), as Daphnia is a keystone species in aquatic food webs and one of the most effective grazers of phytoplankton. Copepods and cladocerans differ in their responses to UVR, with copepods using protective pigments, while cladocerans are more likely to exhibit DVM (Hansson et al. 2007b).

Ultraviolet radiation affects phytoplankton growth, community structure and nutritional quality, and thus has potential consequences for zooplankton grazers. A number of studies demonstrated that phytoplankton growth rates decrease under UVR (e.g., Xenopoulos et al. 2002; Germ et al. 2004); however, some algae successfully cope with increased UV stress (Sinha et al. 1998). Algae exposed to UVR have found to be of reduced nutritional quality for zooplankton (Hessen et al. 1997; De Lange and Van Donk 1997; Gulati and Demott 1997). Daphnids fed on UVB-irradiated algae showed decreased size, reduced growth rates, and reduced fecundity (De Lange and Van Donk 1997; Scott et al. 1999; De Lange and Van Reeuwijk 2003), but Leu et al. (2006) found no significant effect on Daphnia magna (Straus, 1820). How UV-irradiated algae act upon zooplankton grazing rates is difficult to predict and seems to depend on the food item and grazer used in the study (Scott et al. 1999; Germ et al. 2004). Temperature and UVR appear to interact in controlling phytoplankton growth rates and community structure (Williamson et al. 2010). UVB radiation thus has strong implication for food web dynamics by modifying the energy transfer between trophic levels (Xenopoulos et al. 2002; De Lange and Van Reeuwijk 2003).

\section{Beyond the bird's eye view: the modeling approach}

The development of a model of the climate system based on different emission scenarios, reflecting estimates of economic trends and greenhouse gas emissions both from optimistic and pessimistic points of view, allows one to asses potential future impacts of 
climate change (IPCC 2007). These models, referred to as general circulation models (GCM) and their regional counterparts (regional circulation modelsRCMs), are capable of making quantitative predictions of future climate and thus their outputs have recently been used in biological models.

Peeters et al. (2007b) distinguished between two modeling approaches in aquatic ecology: one focusing on phytoplankton response with minimalist models (Gragnani et al. 1999; Huisman et al. 2002; Huppert et al. 2002), and a second one with more sophisticated models including modeling of nutrient and population dynamics. Nutrient-phytoplankton-zooplankton (NPZ) models have frequently been used to predict zooplankton dynamics, where species of similar ecological functions are grouped into functional groups (guild) (see Richardson 2008 and references therein). Now, we have a look at the models relevant to climate change studies:

1. The first approach includes hydrological models or model systems of physical origin often associated with chemical factors. These models operate on the premise that the abiotic template varies with changing climate and populations will reflect those variation (e.g., Hostetler and Small 1999; Blenckner et al. 2002; Gooseff et al. 2005; Andersen et al. 2006).

2. A second type of approach serves quantitative forecasts about community attributes or population and food web dynamics. Based on the complexity dimension and the assumptions they work with, those models can be further refined:

(a) First, several models focus on special issues of great importance. These models can be fairly complex with a number of input parameters; nevertheless, they operate only within a narrow range of assumptions attributed to the specific question the model is created to solve or the specific environment the model works in (e.g., Hartman et al. 2006; Matulla et al. 2007; Peeters et al. 2007b).

(b) Second, ecosystem models operate with a number of variables (e.g., nutrients and light) often coupled with physical models (e.g., Krivtsov et al. 2001; Malmaeus and Håkanson 2004; Elliott et al. 2005; Mooij et al. 2007; Komatsu et al. 2007). Such models run the risk of being too complicated owing to the vast number of variables (Omlin et al. 2001).

(c) Third, tactical models represent an alternative approach of a larger degree of uncertainty. Such an approach neglects some ultimate drivers and tends to focus on the core of the process, still it can provide fairly significant pieces of a puzzle when the overall system behavior is to be disentangled. Such models do not aimed at serving biological interpretation of mathematical operations, rather stress predictions of considerable applicability (e.g., Hufnagel and Gaál 2005; Sipkay et al. 2008, 2009, 2012; Vadadi-Fülöp et al. 2009).

Beyond doubt, ecosystem models are the best option for a more deeper understanding as to how climate change will act upon zooplankton communities. Stateof-the-art approaches also begin to realize the emerging role of indirect community interactions. The methodology of models that can bring significant pieces of information to the field of climate research, however, has not yet been elaborated to the desired level (Sipkay et al. 2009). There is a lack of synthetic models requiring quite a large number of variables which simply cannot be measured, obtained, or even grasped the significance. That is why ecologists by necessity make a compromise between exactitude and reality and create tactical models aiming at underlining the most important variables accounting for the major variation in community dynamics. One sophisticated example is to validate a strategic model of a theoretical community to field data and then develop a tactical model (e.g., Sipkay et al. 2012). The choice also depends on whether we are interested in the interpretation of some a priori time series (tactical models) or the objective is to shed some new light on a theory (strategic models).

\section{Conclusions}

It is now increasingly recognized that freshwater zooplankton have exhibited shifts in phenology, abundance, distribution, size spectra, and community structure in response to climate change. Despite some coherence in patterns, the direction and magnitude of those changes seem to be dependent on system properties and species. The phenology shift reported 
for freshwater zooplankton matches or even exceeds those of the marine zooplankton and terrestrial species. Many species of zooplankton have advanced their phenology either directly in response to the climate signal or indirectly. The different rates of shift between predator and prey or the lack of shift in either of them have the potential to decouple trophic interactions in food webs. This mismatch in phenology has been documented in freshwater zooplankton as well, the frequency of which, however, is currently unknown.

A significant portion of studies are centered upon the relationship between interannual variation of zooplankton time series and large-scale climate patterns. The usefulness of climate indices in plankton ecology received considerable support. However, intrinsic density-dependent and extrinsic density-independent processes (e.g., climate change) often interact in a nonlinear way; therefore, predicting the possible effects of climate forcing on population dynamics remains to be a great challenge (Stenseth et al. 2002).

Ives (1995) suggests that species with unique ecological functions, that is, those that interact strongly with others, are strongly buffered against environmental change because community interactions create strong negative feedbacks against change in their mean density. What stems from this theory is that strongly interacting species might make poor indicators of climate change (Ives 1995); thus, Daphnia, known as a keystone species (Lampert 2006), may have more limited relevance in climate research than previously assumed. What impact will this hypothesis have on aquatic ecology? As we have seen, overwhelming evidence of climate change impact on zooplankton comes from Daphnia studies; therefore, in the future, ecologists should expand their research on species beyond daphnids.

Much of our recent understanding of climate change-related impacts on freshwater zooplankton derives from lakes. Nevertheless, we expect climate change to shape riverine zooplankton (potamoplankton) communities as severe as lake plankton. Owing to the four-dimensional nature of running waters (Ward 1989), the response of zooplankton may show some unique features, for example, shift in biomass maximum in upstream or downstream directions as has been demonstrated for phytoplankton in the Elbe River (Quiel et al. 2011). The outcome may vary considerably depending on future streamflow patterns, which represent an additional stochastic component in predicting plankton dynamics of running waters. In many regions, an increasing magnitude and frequency of floods are projected to occur (Kundzewicz et al. 2007), which can act as reset mechanisms or can restructure plankton assemblages.

Although there is a need for continuing long-term monitoring programmes worldwide, the authors suspect that dozens of time series exist without being placed into a global change framework. This solid body of data may be of particular applicability, because ecological models need to be validated against long-term series. On the other hand, many time series are not easy to access or simply have not been digitalized yet. However, it is not an easy task to disentangle the effects of climate change and confounded impacts of eutrophication and other anthropogenic pressures in time series analyses. A key question remains how to differentiate between different direct and indirect effects of climate change. Fitting together the triad of empirical, experimental, and modeling perspectives will bring into a better understanding of climate warming-related patterns in ecology.

In the future, studies may benefit from (1) moving beyond correlative approaches toward more mechanistic explanations, (2) addressing questions as to how different intrinsic and extrinsic drivers interact, (3) using functional groups as possible indicators of climate change rather than single species, (4) contrasting results obtained from local weather variables and large-scale climate indices, (5) facilitating transfer of biological data both across space and time so as to establish plankton databases with open access similarly to the marine alternatives (e.g., COPEPOD-Coastal \& Oceanic Plankton Ecology, Production \& Observation Database; CPR - Continuous Plankton Recorder Survey), (6) paying more attention to running waters, $\mathrm{UV}$-induced effects and species beyond daphnids.

Acknowledgments This work was supported by the Bolyai János Research Scholarship of the Hungarian Academy of Sciences, "ALÖKI" Applied Ecological Research and Forensic Institute Ltd., and the TÁMOP 4.2.1/B-09/1/KMR-2010-0005 project.

\section{References}

Abrusán G (2004) Filamentous cyanobacteria, temperature and Daphnia growth: the role of fluid mechanics. Oecologia 141:395-401 
Adrian R, Deneke R (1996) Possible impact of mild winters on zooplankton succession in eutrophic lakes of the Atlantic European area. Freshw Biol 36:757-770

Adrian R, Walz N, Hintze T, Hoeg S, Rusche R (1999) Effects of ice duration on plankton succession during spring in a shallow polymictic lake. Freshw Biol 41:621-634

Adrian R, Wilhelm S, Gerten D (2006) Life-history traits of lake plankton species may govern their phenological response to climate warming. Glob Chang Biol 12:652-661

Adrian R, O'Reilly CM, Zagarese H, Baines SB, Hessen DO, Keller W et al (2009) Lakes as sentinels of climate change. Limnol Oceanogr 54:2283-2297

Allan RJ, Lindesay J, Parker D (1996) El Nino-Southern Oscillation and climatic variability. CSIRO Publishing, Collingwood

Allen AP, Brown JH, Gillooly JF (2002) Global biodiversity, biochemical kinetics and the energetic-equivalence rule. Science 297:1545-1548

Alonso C, Rocco V, Barriga JP, Battini MA, Zagarese H (2004) Surface avoidance by freshwater zooplankton: field evidence on the role of ultraviolet radiation. Limnol Oceanogr 49:225-232

Alvarez-Cobelas M, Rojo C (2000) Ecological goal functions and plankton communities in lakes. J Plankton Res 22:729-748

Andersen HE, Kronvang B, Larsen SE, Hoffmann CC, Jensen TS, Rasmussen EK (2006) Climate-change impacts on hydrology and nutrients in a Danish lowland river basin. Sci Total Environ 365:223-237

Arnott SE, Yan ND (2002) The influence of drought and re-acidification on zooplankton emergence from resting stages. Ecol Appl 12:138-153

Arnott SE, Keller B, Dillon PJ, Yan N, Paterson M, Findlay D (2003) Using temporal coherence to determine the response to climate change in Boreal Shield Lakes. Environ Monit Assess 88:365-388

Arora VK, Boer GJ (2001) Effects of simulated climate change on the hydrology of major river basins. J Geophys Res 106:3335-3348

Atkinson D (1994) Temperature and organism size-a biological law for ectotherms? Adv Ecol Res 25:1-58

Atkinson D (1995) Effects of temperature on the size of aquatic ectotherms: exceptions to the general rule. J Therm Biol 20:61-74

Atkinson D, Sibly RM (1997) Why are organisms usually bigger in colder environments? Making sense of a life history puzzle. Trends Ecol Evol 12:235-239

Atkinson D, Ciotti BJ, Montagnes DJS (2003) Protists decrease in size linearly with temperature: ca. $2.5 \%{ }^{\circ} \mathrm{C}-1$. Proc R Soc B 270:2605-2611

Battarbee RW (2000) Palaeolimnological approaches to climate change, with special regard to the biological record. Quat Sci Rev 19:107-124

Benndorf J, Kranich J, Mehner T, Wagner A (2001) Temperature impact on the midsummer decline of Daphnia galeata: an analysis of long-term data from the biomanipulated Bautzen Reservoir (Germany). Freshw Biol 46:199-211

Blenckner T, Omstedt A, Rummukainen M (2002) A Swedish case study of contemporary and possible future consequences of climate change on lake function. Aquat Sci 64:171-184
Blenckner T, Adrian R, Livingstone DM, Jennings E, Weyhenmeyer GA, George DG et al (2007) Large-scale climatic signatures in lakes across Europe: a meta-analysis. Glob Chang Biol 13:1314-1326

Brett MT, Müller-Navarra DC (1997) The role of highly unsaturated fatty acids in aquatic foodweb processes. Freshw Biol 38:483-499

Brooks JL, Dodson SI (1965) Predation, body size, and composition of plankton. Science 150:28-35

Brown JH, Gillooly JF, Allen AP, Savage VM, West GB (2004) Toward a metabolic theory of ecology. Ecology 85: 1771-1789

Cabrera S, López M, Tartarotti B (1997) Phytoplankton and zooplankton response to ultraviolet radiation in a highaltitude Andean lake: short- versus long-term effects. J Plankton Res 19:1565-1582

Cáceres CE (1998) Interspecific variation in the abundance, production and emergence of Daphnia diapausing eggs. Ecology 79:1699-1710

Cáceres CE, Schwalbach MS (2001) How well do laboratory experiments explain field patterns of zooplankton emergence? Freshw Biol 46:1179-1189

Chen CY, Folt CL (1996) Consequences of fall warming for zooplankton overwintering success. Limnol Oceanogr 41:1077-1086

Chen CY, Folt CL (2002) Ecophysiological responses to warming events by two sympatric zooplankton species. J Plankton Res 24:579-589

Chivas AR, De Deckker P, Shelley JMG (1985) Strontium content of ostracods indicates lacustrine palaeosalinity. Nature 316:251-253

Coats R, Perez-Losada J, Schladow G, Richards R, Goldman C (2006) The warming of Lake Tahoe. Clim Chang 76:121-148

Cooke SL, Williamson CE, Saros JE (2006) How do temperature, dissolved organic matter and nutrients influence the response of Leptodiaptomus ashlandi to UV radiation in a subalpine lake? Freshw Biol 51:1827-1837

Cushing DH (1969) The regularity of the spawning season of some fishes. ICES J Mar Sci 33:81-92

Daufresne M, Lengfellner K, Sommer U (2009) Global warming benefits the small in aquatic ecosystems. Proc Natl Acad Sci USA 106:12788-12793

De Lange HJ, Van Donk E (1997) Effects of UVB-irradiated algae on life history traits of Daphnia pulex. Freshw Biol 38:711-720

De Lange HJ, Van Reeuwijk PL (2003) Negative effects of UVB-irradiated phytoplankton on life history traits and fitness of Daphnia magna. Freshw Biol 48:678-686

De Senerpont Domis LNW, Mooij M, Huisman J (2007a) Climate-induced shifts in an experimental phytoplankton community: a mechanistic approach. Hydrobiologia 584: 403-413

De Senerpont Domis LNW, Mooij M, Hülsmann S, Van Nes EH, Scheffer M (2007b) Can overwintering versus diapausing strategy in Daphnia determine match-mismatch events in zooplankton-algae interactions? Oecologia 150: 682-698

De Stasio BT, Hill DK, Kleinhans JM, Nibbelink NP, Magnuson JJ (1996) Potential effects of global climate change on small north-temperate lakes: physics, fish, and plankton. Limnol Oceanogr 41:1136-1149 
Deksne R, Škute A, Paidere J (2010) Changes in structure of zooplankton communities in the middle Daugava (Western Dvina) over the last five decades. Acta Zool Litu 20: 190-208

Diehl S, Berger S, Ptacnik R, Wild A (2002) Phytoplankton, light, and nutrients in a gradient of mixing depths: field experiments. Ecology 83:399-411

Dokulil MT, Herzig A (2009) An analysis of long-term winter data on phytoplankton and zooplankton in Neusiedler See, a shallow temperate lake, Austria. Aquat Ecol 43:715-725

Drake JM (2005) Population effects of increased climate variation. Proc R Soc B 272:1823-1827

Dukes JS, Mooney HA (1999) Does global change increase the success of biological invaders? Trends Ecol Evol 14: 135-139

Dupuis AP, Hann BJ (2009a) Warm spring and summer water temperatures in small eutrophic lakes of the Canadian prairies: potential implications for phytoplankton and zooplankton. J Plankton Res 31:489-502

Dupuis AP, Hann BJ (2009b) Climate change, diapause termination and zooplankton population dynamics: an experimental and modelling approach. Freshw Biol 54:221-235

Durant JM, Hjermann DO, Ottersen G, Stenseth NC (2007) Climate and the match or mismatch between predator requirements and resource availability. Clim Res 33: 271-283

Edwards M, Richardson A (2004) Impact of climate change on marine pelagic phenology and trophic mismatch. Nature 430:881-884

Elliott JA (2010) The seasonal sensitivity of cyanobacteria and other phytoplankton to changes in flushing rate and water temperature. Glob Chang Biol 16:864-876

Elliott JA, Thackeray SJ, Huntingford C, Jones RG (2005) Combining a regional climate model with a phytoplankton community model to predict future changes in phytoplankton in lakes. Freshw Biol 50:1404-1411

Fang X, Stefan HG, Alam SR (1999) Simulation and validation of fish thermal DO habitat in north-central US lakes under different climate scenarios. Ecol Modell 118:167-191

Folke C, Carpenter S, Walker B, Scheffer M, Elmqvist T, Gunderson L et al (2004) Regime shifts, resilience, and biodiversity in ecosystem management. Annu Rev Ecol Evol Syst 35:557-581

Fulton RS, Paerl HW (1988) Effects of the blue-green alga Microcystis aeruginosa on zooplankton competitive relations. Oecologia 76:383-389

Gaedke U, Ollinger D, Bauerle E, Straile D (1998) The impact of the interannual variability in hydrodynamic conditions on the plankton development in Lake Constance in spring and summer. Adv Limnol 53:565-585

George DG (2000) The impact of regional-scale changes in the weather on the long-term dynamics of Eudiaptomus and Daphnia in Esthwaite Water, Cumbria. Freshw Biol 45:111-121

George DG, Harris GP (1985) The effect of climate on longterm changes in the crustacean zooplankton biomass of Lake Windermere, UK. Nature 316:536-539

George DG, Hewitt DP, Lund JWG, Smyly WJP (1990) The relative effects of enrichment and climate change on the long-term dynamics of Daphnia in Esthwaite Water, Cumbria. Freshw Biol 23:55-70
Germ M, Simcic T, Gaberscik A, Breznik B, Hrastel M (2004) UV-B treated algae exhibiting different responses as a food source for Daphnia magna. J Plankton Res 26:1219-1228

Gerten D, Adrian R (2000) Climate-driven changes in spring plankton dynamics and the sensitivity of shallow polymictic lakes to the North Atlantic Oscillation. Limnol Oceanogr 45:1058-1066

Giebelhausen B, Lampert W (2001) Temperature reaction norms of Daphnia magna: the effect of food concentration. Freshw Biol 46:281-289

Gilbert JJ, Schröder T (2004) Rotifers from diapausing, fertilized eggs: unique features and emergence. Limnol Oceanogr 49:1341-1354

Gillooly JF, Brown JH, West GB, Savage VM, Charnov EL (2001) Effects of size and temperature on metabolic rate. Science 293:2248-2251

Gillooly JF, Charnov EL, West GB, Savage VM, Brown JH (2002) Effects of size and temperature on developmental time. Nature 417:70-73

Gooseff MN, Strzepek K, Chapra SC (2005) Modeling the potential effects of climate change on water temperature downstream of a shallow reservoir, Lower Madison River, MT. Clim Chang 68:331-353

Gophen M (1976a) Temperature effect on lifespan, metabolism, and development time of Mesocyclops leuckarti (Claus). Oecologia 25:271-277

Gophen M (1976b) Temperature dependence of food intake, ammonia excretion and respiration in Ceriodaphnia reticulata (Jurine) (Lake Kinneret, Israel). Freshw Biol 6: 451-455

Grad G, Burnett BJ, Williamson CE (2003) UV damage and photoreactivation: timing and age are everything. Photochem Photobiol 78:225-227

Gragnani A, Scheffer M, Rinaldi S (1999) Top-down control of cyanobacteria: a theoretical analysis. Am Nat 153:59-72

Gulati R, Demott W (1997) The role of food quality for zooplankton: remarks on the state-of-the-art, perspectives and priorities. Freshw Biol 38:753-768

Gyllström M, Hansson LA (2004) Dormancy in freshwater zooplankton: induction, termination and the importance of benthic-pelagic coupling. Aquat Sci 66:274-295

Gyllström M, Hansson LA, Jeppesen E, García-Criado F, Gross $\mathrm{E}$, Irvine $\mathrm{K}$ et al (2005) The role of climate in shaping zooplankton communities in shallow lakes. Limnol Oceanogr 50:2008-2021

Häder DP, Kumar HD, Smith RC, Worrest RC (2003) Aquatic ecosystems: effects of solar ultraviolet radiation and interactions with other climatic change factors. Photochem Photobiol Sci 2:39-50

Hairston NG (1996) Zooplankton egg banks as biotic reservoirs in changing environments. Limnol Oceanogr 41:10871092

Hairston NG, Kearns CM (2002) Temporal dispersal: ecological and evolutionary aspects of zooplankton egg banks and the role of sediment mixing. Integr Comp Biol 42:481-491

Hallett TB, Coulson T, Pilkington JG, Clutton-Brock TH, Pemberton JM, Grenfell BT (2004) Why large-scale climate indices seem to predict ecological processes better than local weather. Nature 430:71-75

Hampton SE, Izmest'eva LR, Moore MV, Katz SL, Dennis B, Silow EA (2008) Sixty years of environmental change in 
the world's largest freshwater lake-Lake Baikal, Siberia. Glob Chang Biol 14:1947-1958

Haney JF (1987) Field studies on zooplankton-cyanobacteria interactions. N Z J Mar Freshw Res 21:467-475

Hansson LA, Gustafsson S, Rengefors K, Bomark L (2007a) Cyanobacterial chemical warfare affects zooplankton community composition. Freshw Biol 52:1290-1301

Hansson LA, Hylander S, Sommaruga R (2007b) Escape from UV threats in zooplankton: a cocktail of behavior and protective pigmentation. Ecology 88:1932-1939

Hartman MD, Baron JS, Ojima DS (2006) Application of a coupled ecosystem chemical equilibrium model, DayCentChem, to stream and soil chemistry in a Rocky Mountain watershed. Ecol Modell 200:493-510

Hartmann DL, Wallace JM, Limpasuvan V, Thompson DWJ, Holton JR (2000) Can ozone depletion and global warming interact to produce rapid climate change? Proc Natl Acad Sci USA 97:1412-1417

Havel JE, Medley KA (2006) Biological invasions across spatial scales: intercontinental, regional, and local dispersal of cladoceran zooplankton. Biol Invasions 8:459-473

Hays GC, Richardson AJ, Robinson C (2005) Climate change and marine plankton. Trends Ecol Evol 20:337-344

Heino J, Virkkala R, Toivonen H (2009) Climate change and freshwater biodiversity: detected patterns, future trends and adaptations in northern regions. Biol Rev 84:39-54

Helland IP, Freyhof J, Kasprzak P, Mehner T (2007) Temperature sensitivity of vertical distributions of zooplankton and planktivorous fish in a stratified lake. Oecologia 151: 322-330

Hessen DO, De Lange HJ, Van Donk E (1997) UV-induced changes in phytoplankton cells and its effects on grazers. Freshw Biol 38:513-524

Hietala J, Laurén-Määttä C, Walls M (1997) Sensitivity of Daphnia to toxic cyanobacteria: effects of genotype and temperature. Freshw Biol 37:299-306

Hostetler SW, Small EE (1999) Response of North American freshwater lakes to simulated future climates. J Am Water Resour Assoc 35:1625-1637

Huber V, Adrian R, Gerten D (2010) A matter of timing: heat wave impact on crustacean zooplankton. Freshw Biol 55:1769-1779

Hufnagel L, Gaál M (2005) Seasonal dynamic pattern analysis in service of climate change research. Appl Ecol Environ Res 3:79-132

Huisman J, Arrayas SK, Ebert U, Sommeijer B (2002) How do sinking phytoplankton species manage to persist? Am Nat 159:245-254

Huisman J, Sharples J, Stroom JM, Visser PM, Kardinaal WEA, Verspagen JMH et al (2004) Changes in turbulent mixing shift competition for light between phytoplankton species. Ecology 85:2960-2970

Huppert A, Blasius B, Stone L (2002) A model of phytoplankton blooms. Am Nat 159:156-171

Hurrell JW (1995) Decadal trends in the North Atlantic Oscillation: regional temperatures and precipitation. Science 269:676-679

IPCC (2007) Climate change 2007: the physical science basis. Working group I contribution to the fourth assessment report of the IPCC. Intergovernmental Panel of Climate Change, Cambridge University Press, New York
Ives AR (1995) Predicting the response of populations to environmental change. Ecology 76:926-941

Jackson LJ, Lauridsen TL, Sondergaard M, Jeppesen E (2007) A comparison of shallow Danish and Canadian lakes and implications of climate change. Freshw Biol 52:1782-1792

Jeppesen E, Kronvang B, Meerhoff M, Sondergaard M, Hansen KM, Andersen HE et al (2009) Climate change effects on runoff, catchment phosphorus loading and lake ecological state, and potential adaptations. J Environ Qual 38: 1930-1941

Jeppesen E, Meerhoff M, Holmgren K, González-Bergonzoni I, Teixeira-de Mello F, Declerck SAJ et al (2010) Impacts of climate warming on lake fish community structure and potential effects on ecosystem function. Hydrobiologia 646:73-90

Jöhnk KD, Huisman J, Sharples J, Sommeijer B, Visser PM, Stroom JM (2008) Summer heatwaves promote blooms of harmful cyanobacteria. Glob Chang Biol 14:495-512

Johnson AC, Acreman MC, Dunbar MJ, Feist SW, Giacomello AM, Gozian RE et al (2009) The British river of the future: how climate change and human activity might affect two contrasting river ecosystems in England. Sci Total Environ 407:4787-4798

Jones ID, Page T, Elliott JA, Thackeray SJ, Heathwaite AL (2011) Increases in lake phytoplankton biomass caused by future climate-driven changes to seasonal river flow. Glob Chang Biol 17:1809-1820

King JR, Shuter BJ, Zimmerman AP (1997) The response of the thermal stratification of South Bay (Lake Huron) to climatic variability. Can J Fish Aquat Sci 54:1873-1882

Komatsu E, Fukushima T, Harasawa H (2007) A modeling approach to forecast the effect of long-term climate change on lake water quality. Ecol Modell 209:351-366

Krivtsov V, Goldspink C, Sigee DC, Bellinger EG (2001) Expansion of the model "Rostherne" for fish and zooplankton: role of top-down effects in modifying the prevailing pattern of ecosystem functioning. Ecol Modell 138:153-171

Kundzewicz ZW, Mata LJ, Arnell NW, Döll P, Kabat P, Jiménez B et al (2007) Freshwater resources and their management. In: Parry ML, Canziani OF, Palutikof JP, van der Linden PJ, Hanson CE (eds) Climate change 2007: impacts, adaptation and vulnerability. Contribution of working group II to the fourth assessment report of the Intergovernmental Panel on Climate Change. Cambridge University Press, Cambridge, pp 173-210

Lampert W (2006) Daphnia: model, herbivore, predator and prey. Pol J Ecol 54:607-620

Lampert W (2011) Daphnia: development of a model organism in ecology and evolution. In: Kinne O (ed) Excellence in ecology, vol 21. International Ecology Institute, Oldendorf/Luhe

Lampert W, Fleckner W, Rai H, Taylor BE (1986) Phytoplankton control by grazing zooplankton: a study on the spring clear-water phase. Limnol Oceanogr 31:478-490

Leech DM, Williamson CE (2000) Is tolerance to UV radiation in zooplankton related to body size, taxon, or lake transparency? Ecol Appl 10:1530-1540

Leech DM, Padeletti A, Williamson CE (2005) Zooplankton behavioral responses to solar UV radiation vary within and among lakes. J Plankton Res 27:461-471 
Lennon JT, Smith VH, Williams K (2001) Influence of temperature on exotic Daphnia lumholtzi and implications for invasion success. J Plankton Res 23:425-434

Leu E, Faerovig PJ, Hessen DO (2006) UV effects on stoichiometry and PUFAs of Selenastrum capricornutum and their consequences for the grazer Daphnia magna. Freshw Biol 51:2296-2308

Livingstone DM (2003) Impact of secular climate change on the thermal structure of a large temperate central European lake. Clim Chang 57:205-225

Loreau M, Naeem S, Inchausti P, Bengtsson J, Grime JP, Hector A et al (2001) Biodiversity and ecosystem functioning: current knowledge and future challenges. Science 294 : 804-808

Lotter AF, Birks HJB, Hofmann W, Marchetto A (1997) Modern diatom, cladocera, chironomid, and crysophyte cyst assemblages as quantitative indicators for the reconstruction of past environmental conditions in the Alps. I. Climate. J Paleolimnol 18:395-420

Magnuson JJ, Robertson DM, Benson BJ, Wynne RH, Livingstone DM, Arai T et al (2000) Historical trends in lake and river ice cover in the northern hemisphere. Science 289:1743-1746

Malmaeus JM, Håkanson L (2004) Development of a lake eutrophication model. Ecol Modell 171:35-63

Manca M, DeMott WR (2009) Response of the invertebrate predator Bythotrephes to a climate-linked increase in the duration of a refuge from fish predation. Limnol Oceanogr 54:2506-2512

Manca M, Portogallo M, Brown ME (2007) Shifts in phenology of Bythotrephes longimanus and its modern success in Lake Maggiore as a result of changes in climate and trophy. J Plankton Res 29:515-525

Mantua NJ, Hare SR, Zhang Y, Wallace JM, Francis RC (1997) A Pacific interdecadal climate oscillation with impacts on salmon production. Bull Am Meteorol Soc 78:1069-1079

Matulla C, Schmutz S, Melcher A, Gerersdorfer T, Haas P (2007) Assessing the impact of a downscaled climate change simulation on the fish fauna in an Inner-Alpine River. Int J Biometeorol 52:127-137

McCann KS (2000) The diversity-stability debate. Nature 405:228-233

McCann KS, Hastings A, Huxel GR (1998) Weak trophic interactions and the balance of nature. Nature 395:794-798

McGowan S, Leavitt PR, Hall RI (2005) A whole-lake experiment to determine the effects of winter droughts on shallow lakes. Ecosystems 8:694-708

McKee D, Ebert D (1996) The effect of temperature on maturation threshold body-length in Daphnia magna. Oecologia 108:627-630

McKee D, Atkinson D, Collings S, Eaton J, Harvey I, Heyes T et al (2002) Macro-zooplankter responses to simulated climate warming in experimental freshwater microcosms. Freshw Biol 47:1557-1570

Mehner T (2000) Influence of spring warming on the predation rate of underyearling fish on Daphnia-a deterministic simulation approach. Freshw Biol 45:253-263

Mitchell SE, Rogers ES, Little TJ, Read AF (2005) Host-parasite and genotype-by-environment interactions: temperature modifies potential for selection by a sterilizing pathogen. Evolution 59:70-80
Molinero JC, Anneville O, Souissi S, Balvay G, Gerdeaux D (2006) Anthropogenic and climate forcing on the longterm changes of planktonic rotifers in Lake Geneva, Europe. J Plankton Res 28:287-296

Mooij WM, Hülsmann S, De Senerpont Domis LN, Nolet BA, Bodelier PLE, Boers PCM et al (2005) The impact of climate change on lakes in The Netherlands: a review. Aquat Ecol 39:381-400

Mooij WM, Janse JH, De Senerpont Domis LN, Hülsmann S, Ibelings BW (2007) Predicting the effect of climate change on temperate shallow lakes with the ecosystem model PCLake. Hydrobiologia 584:443-454

Moore MV, Folt CL (1993) Zooplankton body size and community structure: effects of thermal and toxicant stress. Trends Ecol Evol 8:178-183

Moore MV, Folt CL, Stemberger RS (1996) Consequences of elevated temperatures for zooplankton assemblages in temperate lakes. Arch Hydrobiol 135:289-319

Moss B, McKee D, Atkinson D, Collings SE, Eaton JW, Gill $A B$ et al (2003) How important is climate? Effects of warming, nutrient addition and fish on phytoplankton in shallow lake microcosms. J Appl Ecol 40: 782-792

Norberg J, DeAngelis D (1997) Temperature effects on stocks and stability of a phytoplankton-zooplankton model and the dependence on light and nutrients. Ecol Modell 95: 75-86

Omlin M, Brun R, Reichert P (2001) Biogeochemical model of Lake Zurich: sensitivity, identifiability and uncertainty analysis. Ecol Modell 141:105-123

Ottersen G, Planque B, Belgrano A, Post E, Reid PC, Stenseth NC (2001) Ecological effects of the North Atlantic Oscillation. Oecologia 128:1-14

Paerl HW, Huisman J (2009) Climate change: a catalyst for global expansion of harmful cyanobacterial blooms. Environ Microbiol Rep 1:27-37

Park S, Brett MT, Müller-Solger A, Goldman CR (2004) Climatic forcing and primary productivity in a subalpine lake: interannual variability as a natural experiment. Limnol Oceanogr 49:614-619

Parmesan C (2007) Influences of species, latitudes and methodologies on estimates of phenological response to global warming. Glob Chang Biol 13:1860-1872

Parmesan C, Yohe G (2003) A globally coherent fingerprint of climate change impacts across natural systems. Nature 421:37-42

Paul VJ (2008) Global warming and cyanobacterial harmful algal blooms. In: Hudnell HK (ed) Cyanobacterial harmful algal blooms: state of the science and research needs. Advances in experimental medicine and biology, vol 619. Springer, Berlin, pp 239-257

Peeters F, Straile D, Lorke A, Livingstone DM (2007a) Earlier onset of the spring phytoplankton bloom in lakes of the temperate zone in a warmer climate. Glob Chang Biol 13:1898-1909

Peeters F, Straile D, Lorke A, Ollinger D (2007b) Turbulent mixing and phytoplankton spring bloom development in a deep lake. Limnol Oceanogr 52:286-298

Perkins DM, Reiss J, Yvon-Durocher G, Woodward G (2010) Global change and food webs in running waters. Hydrobiologia 657:181-198 
Persaud AD, Williamson CE (2005) Ultraviolet and temperature effects on planktonic rotifers and crustaceans in northern temperate lakes. Freshw Biol 50:467-476

Petchey OL, McPhearson PT, Casey TM, Morin PJ (1999) Environmental warming alters food-web structure and ecosystem function. Nature 402:69-72

Phlips EJ, Hendrickson J, Quinlan EL, Cichra M (2007) Meteorological influences on algal bloom potential in a nutrientrich blackwater river. Freshw Biol 52:2141-2155

Poff NL (2002) Ecological response to and management of increased flooding caused by climate change. Philos Trans R Soc A 360:1497-1510

Poff NL, Allan JD, Bain MB, Karr JR, Prestegaard KL, Richter $\mathrm{BD}$ et al (1997) The natural flow regime. Bioscience 47:769-784

Porter KG, McDonough R (1984) The energetic cost of response to blue-green algal filaments by cladocerans. Limnol Oceanogr 29:365-369

Preston ND, Rusak JA (2010) Homage to Hutchinson: does inter-annual climate variability affect zooplankton density and diversity? Hydrobiologia 653:165-177

Quiel K, Becker A, Kirchesch V, Schöl A, Fischer H (2011) Influence of global change on phytoplankton and nutrient cycling in the Elbe River. Reg Environ Chang 11:405-421

Rahel FJ, Olden JD (2008) Assessing the effects of climate change on aquatic invasive species. Conserv Biol 22: $521-533$

Reynolds CS (1984) The ecology of freshwater phytoplankton. Cambridge University Press, Cambridge

Richardson AJ (2008) In hot water: zooplankton and climate change. ICES J Mar Sci 65:279-295

Robarts RD, Zohary T (1987) Temperature effects on photosynthetic capacity, respiration, and growth rates of bloomforming cyanobacteria. N Z J Mar Freshw Res 21:391-399

Root TL, Price JT, Hall KR, Schneider SH, Rosenzweig C, Pounds A (2003) Fingerprints of global warming on wild animals and plants. Nature 421:57-60

Rusak JA, Yan ND, Somers KM (2008) Regional climatic drivers of synchronous zooplankton dynamics in northtemperate lakes. Can J Fish Aquat Sci 65:878-889

Sala OE, Ill FSC, Armesto JJ, Berlow E, Bloomfield J, Dirzo R et al (2000) Global biodiversity scenarios for the year 2100. Science 287:1770-1774

Sarma SSS, Nandini S, Gulati RD (2005) Life history strategies of cladocerans: comparisons of tropical and temperate taxa. Hydrobiologia 542:315-333

Savage VM, Gillooly JF, Brown JH, West GB, Charnov EL (2004) Effects of body size and temperature on population growth. Am Nat 163:429-441

Schalau K, Rinke K, Straile D, Peeters F (2008) Temperature is the key factor explaining interannual variability of Daphnia development in spring: a modelling study. Oecologia 157:531-543

Scheffer M, Van Nes EH (2007) Shallow lakes theory revisited: various alternative regimes driven by climate, nutrients, depth and lake size. Hydrobiologia 584:455-466

Scheffer M, Hosper SH, Meijer ML, Moss B, Jeppesen E (1993) Alternative equilibria in shallow lakes. Trends Ecol Evol 8:275-279

Scheffer M, Carpenter S, Foley JA, Folke C, Walker B (2001) Catastrophic shifts in ecosystems. Nature 413:591-596
Schindler DW (1997) Widespread effects of climate warming on freshwater ecosystems in North America. Hydrol Process 11:1043-1067

Schindler DW (2009) Lakes as sentinels and integrators for the effects of climate change on watersheds, airsheds, and landscapes. Limnol Oceanogr 54:2349-2358

Schindler DW, Bayley SE, Parker BR, Beaty KG, Cruikshank DR, Fee EJ et al (1996) The effects of climatic warming on the properties of boreal lakes and streams at the Experimental Lakes Area, northwestern Ontario. Limnol Oceanogr 41:1004-1017

Schindler DE, Rogers DE, Scheuerell MD, Abrey CA (2005) Effects of changing climate on zooplankton and juvenile sockeye salmon growth in southwestern Alaska. Ecology 86:198-209

Scott JD, Chalker-Scott L, Foreman AE, D’Angelo M (1999) Daphnia pulex fed UVB-irradiated Chlamydomonas reinhardtii show decreased survival and fecundity. Photochem Photobiol 70:308-313

Shatwell T, Köhler J, Nicklisch A (2008) Warming promotes cold-adapted phytoplankton in temperate lakes and opens a loophole for Oscillatoriales in spring. Glob Chang Biol 14:2194-2200

Shindell DT, Rind D, Lonergan P (1998) Increased polar stratospheric ozone losses and delayed eventual recovery owing to increasing greenhouse-gas concentrations. Nature 392:589-592

Shurin JB, Winder M, Adrian R, Keller WB, Matthews B, Paterson AM et al (2010) Environmental stability and lake zooplankton diversity - contrasting effects of chemical and thermal variability. Ecol Lett 13:453-463

Sinha RP, Klisch M, Gröniger A, Häder DP (1998) Ultravioletabsorbing/screening substances in cyanobacteria, phytoplankton and macroalgae. J Photochem Photobiol B 47: 83-94

Sipkay C, Horváth L, Nosek J, Oertel N, Vadadi-Fülöp C, Farkas E et al (2008) Analysis of climate change scenarios based on modelling of the seasonal dynamics of a Danubian copepod species. Appl Ecol Environ Res 6:101-108

Sipkay C, Kiss KT, Vadadi-Fülöp C, Hufnagel L (2009) Trends in research on the possible effects of climate change concerning aquatic ecosystems with special emphasis on the modelling approach. Appl Ecol Environ Res 7:171-198

Sipkay C, Kiss KT, Vadadi-Fülöp C, Homoródi R, Hufnagel L (2012) Simulation modeling of phytoplankton dynamics in a large eutrophic river, Hungary-Danubian Phytoplankton Growth Model DPGM. Biologia 67:323-337

Spencer C, King D (1987) Regulation of blue-green algal buoyancy and bloom formation by light, inorganic nitrogen, carbon dioxide and trophic level interactions. Hydrobiologia 144:183-192

Stelzer CP (2002) Phenotypic plasticity of body size at different temperatures in a planktonic rotifer: mechanisms and adaptive significance. Funct Ecol 16:835-841

Stemberger RS, Herlihy AT, Kugler DL, Paulsen SG (1996) Climatic forcing on zooplankton richness in lakes of the northeastern United States. Limnol Oceanogr 41: 1093-1101

Stenseth NC, Mysterud A (2005) Weather packages: finding the right scale and composition of climate in ecology. J Anim Ecol 74:1195-1198 
Stenseth NC, Mysterud A, Ottersen G, Hurrell JW, Chan KS, Lima M (2002) Ecological effects of climate fluctuations. Science 297:1292-1296

Storz UC, Paul RJ (1998) Phototaxis in water fleas (Daphnia magna) is differently influenced by visible and UV light? J Comp Physiol A 183:709-717

Straile D (2000) Meteorological forcing of plankton dynamics in a large and deep continental European lake. Oecologia 122:44-50

Straile D (2002) North Atlantic Oscillation synchronizes foodweb interactions in central European Lakes. Proc R Soc B 269:391-395

Straile D, Geller W (1998) The response of Daphnia to changes in trophic status and weather patterns: a case study from Lake Constance. ICES J Mar Sci 55:775-782

Straile D, Müller H (2010) Response of Bosmina to climate variability and reduced nutrient loading in a large lake. Limnologica 40:92-96

Straile D, Stenseth NC (2007) The North Atlantic Oscillation and ecology: links between historical time-series, and lessons regarding future climate warming. Clim Res 34: 259-262

Strecker AL, Cobb TP, Vinebrooke RD (2004) Effects of experimental greenhouse warming on phytoplankton and zooplankton communities in fishless alpine ponds. Limnol Oceanogr 49:1182-1190

Strecker AL, Arnott SE, Yan ND, Girard R (2006) Variation in the response of crustacean zooplankton species richness and composition to the invasive predator Bythotrephes longimanus. Can J Fish Aquat Sci 63:2126-2136

Thackeray SJ, Sparks TH, Frederiksen M, Burthe S, Bacon PJ, Bell JR et al (2010) Trophic level asynchrony in rates of phenological change for marine, freshwater and terrestrial environments. Glob Chang Biol 16:3304-3313

Thomas CD, Cameron A, Green RE, Bakkenes M, Beaumont LJ, Collingham YC et al (2004) Extinction risk from climate change. Nature 427:145-148

Thomas CD, Franco AMA, Hill JK (2006) Range retractions and extinction in the face of climate warming. Trends Ecol Evol 21:415-416

Vadadi-Fülöp C, Türei D, Sipkay C, Verasztó C, Drégelyi-Kiss Á, Hufnagel L (2009) Comparative assessment of climate change scenarios based on aquatic food web modeling. Environ Model Assess 14:563-576

Visconti A, Manca M, De Bernardi R (2008) Eutrophicationlike response to climate warming: an analysis of Lago Maggiore ( $\mathrm{N}$. Italy) zooplankton in contrasting years. J Limnol 67:87-92

Visser ME, Both C (2005) Shifts in phenology due to global climate change: the need for a yardstick. Proc R Soc B 272:2561-2569

Vitousek PM, D’Antonio CM, Loope LL, Rejmánek M, Westbrooks R (1997) Introduced species: a significant component of human-caused global change. N Z J Ecol 21:1-16

Wagner C, Adrian R (2009) Cyanobacteria dominance: quantifying the effects of climate change. Limnol Oceanogr 54:2460-2468

Wagner A, Benndorf J (2007) Climate-driven warming during spring destabilises a Daphnia population: a mechanistic food web approach. Oecologia 151:351-364
Walther GR, Post E, Convey P, Menzei A, Parmesan C, Beebee TJC et al (2002) Ecological responses to recent climate change. Nature 416:389-395

Ward JV (1989) The four-dimensional nature of lotic ecosystems. J N Am Benthol Soc 8:2-8

Webster JC, Peters RH (1978) Some size-dependent inhibitions of larger cladoceran filterers in filamentous suspensions. Limnol Oceanogr 23:1238-1244

Weetman D, Atkinson D (2004) Evaluation of alternative hypotheses to explain temperature-induced life history shifts in Daphnia. J Plankton Res 26:107-116

Williamson CE (1995) What role does UV-B radiation play in freshwater ecosystems? Limnol Oceanogr 40:386-392

Williamson CE, Rose KC (2010) When UV meets fresh water. Science 329:637-639

Williamson CE, Zagarese HE, Schulze PC, Hargreaves BR, Seva J (1994) The impact of short-term exposure to UV-B radiation on zooplankton communities in north temperate lakes. J Plankton Res 16:205-218

Williamson CE, Stemberger RS, Morris DP, Frost TM, Paulsen SG (1996) Ultraviolet radiation in North American lakes: attenuation estimates from DOC measurements and implications for plankton communities. Limnol Oceanogr 41:1024-1034

Williamson CE, Hargreaves BR, Orr PS, Lovera PA (1999) Does UV play a role in changes in predation and zooplankton community structure in acidified lakes? Limnol Oceanogr 44:774-783

Williamson CE, De Lange HJ, Leech DM (2007) Do zooplankton contribute to an ultraviolet clear-water phase in lakes? Limnol Oceanogr 52:662-667

Williamson CE, Dodds W, Kratz TK, Palmer MA (2008) Lakes and streams as sentinels of environmental change in terrestrial and atmospheric processes. Front Ecol Environ $6: 247-254$

Williamson CE, Salm C, Cooke SL, Saros JE (2010) How do UV radiation, temperature, and zooplankton influence the dynamics of alpine phytoplankton communities? Hydrobiologia 648:73-81

Williamson CE, Fischer JM, Bollens SM, Overholt EP, Breckenridge JK (2011) Toward a more comprehensive theory of zooplankton diel vertical migration: integrating ultraviolet radiation and water transparency into the biotic paradigm. Limnol Oceanogr 56:1603-1623

Wilson AE, Sarnelle O, Tillmanns AR (2006) Effects of cyanobacterial toxicity and morphology on the population growth of freshwater zooplankton: meta-analyses of laboratory experiments. Limnol Oceanogr 51:1915-1924

Winder M, Hunter DA (2008) Temporal organization of phytoplankton communities linked to physical forcing. Oecologia 156:179-192

Winder M, Schindler DE (2004a) Climatic effects on the phenology of lake processes. Glob Chang Biol 10:1844-1856

Winder M, Schindler DE (2004b) Climate change uncouples trophic interactions in an aquatic ecosystem. Ecology 85:2100-2106

Winder M, Schindler DE, Essington TE, Litt AH (2009) Disrupted seasonal clockwork in the population dynamics of a freshwater copepod by climate warming. Limnol Oceanogr $54: 2493-2505$ 
Work K, Gophen M (1999) Environmental variability and the population dynamics of the exotic Daphnia lumholtzi and native zooplankton in Lake Texoma, U.S.A. Hydrobiologia 405:11-23

Wrona FJ, Prowse TD, Reist JD, Hobbie JE, Lévesque LMJ, Vincent WF (2006) Climate change effects on aquatic biota, ecosystem structure and function. Ambio 35: 359-369

Xenopoulos MA, Frost PC, Elser JJ (2002) Joint effects of UV radiation and phosphorus supply on algal growth rate and elemental composition. Ecology 83:423-435

Yachi S, Loreau M (1999) Biodiversity and ecosystem productivity in a fluctuating environment: the insurance hypothesis. Proc Natl Acad Sci USA 96:1463-1468
Yan ND, Blukacz A, Sprules WG, Kindy PK, Hackett D, Girard RE et al (2001) Changes in zooplankton and the phenology of the spiny water flea, Bythotrephes, following its invasion of Harp Lake, Ontario, Canada. Can J Fish Aquat Sci 58:2341-2350

Yoo JC, D'Odorico P (2002) Trends and fluctuations in the dates of ice break-up of lakes and rivers in Northern Europe: the effect of the North Atlantic Oscillation. J Hydrol 268: 100-112

Zagarese HE, Williamson CE, Mislivets M, Orr P (1994) The vulnerability of Daphnia to UV-B radiation in the northeastern United States. Adv Limnol 43:207-216 